\title{
KAJIAN PENERAPAN PHT DALAM PELESTARIAN LINGKUNGAN PADA PETANI PADI SAWAH DI KABUPATEN BOLAANG MONGONDOW TIMUR
}

\author{
Arfa Dondo \\ Max Tulung \\ Edy F. Lengkong
}

\begin{abstract}
This study aims to determine how the behavior of farmers in the implementation of Integrated Pest Management (IPM) in terms of three aspects: the ecological aspects, economic aspects and technological aspects. This research was conducted in two districts in East Mongondow Bolaang. Collecting data in this study conducted at 40 farmers of the District Parent and Modayak Modayak West. All farmers are farmers who have participated in the Field School of Integrated Pest Management. The data collection is done by using a questionnaire. The questionnaire was prepared based on measurement principles Likert Scale. The collected data were analyzed using Multiple Linear Regression Analysis. Based on the research, regression equation: $Y=4.240++0,326 \times 30,083 \times 2 \quad 0,07 X 1++e$. Furthermore, based on the results of testing of the F-statistic can be concluded that the ecological aspects, economic aspects and technological aspects together have the same effect on the opinion of the farmer $(Y)$ significantly. This we can see where the F-count is 8,040 and the F-table for 2866, in other words 8,040 F count> F-Table 2866. So the null hypothesis is rejected. It means ecological aspects, economic aspects and technological aspects together have the same effect on the opinion of the farmer $(Y)$. While based on t-test statistics for independent variables namely the ecological aspects, economic aspects and aspects of the technology are as follows: the ecological aspect $t$ calculate equal to 2,422> $t$ table 2028, the economic aspect $t$ calculate equal to 2,083> t table 2,028 and technological aspects $t$ of 2,702> t table 2,028. Thus, ecological aspects, economic aspects and technological aspects have the signigicant effect on the opinion of farmers about IPM.
\end{abstract}

Keywords: environment, integrated pest management, agriculutre, East Bolaang Mongondow Regency, North Sulawesi Province

ABSTRAK

Penelitian ini bertujuan untuk mengetahui bagaimana perilaku petani dalam penerapan Pengendalian Hama Terpadu (PHT) ditinjau dari tiga aspek yaitu: aspek ekologi, aspek ekonomi dan aspek tehnologi. Penelitian ini dilaksanakan di dua kecamatan di Kabupaten Bolaang Mongondow Timur. Pengumpulan data pada penelitian ini dilakukan pada 40 petani dari Kecamatan Modayak Induk dan Modayak Barat. Semua petani adalah petani yang sudah mengikuti kegiatan Sekolah Lapang Pengendalian Hama Terpadu. Pengumpulan data dilakukan dengan menggunakan kuesioner. Kuesioner disusun berdasarkan prinsip pengukuran Skala Likert. Data yang telah dikumpulkan dianalisis dengan menggunakan Analisis Regresi Linier Berganda. Dari hasil penelitian diperoleh persamaan regresinya: Y $=4,240+0,07 \mathrm{X} 1+0,083 \mathrm{X} 2+0,326 \mathrm{X} 3+\mathrm{e}$. Selanjutnya berdasarkan hasil pengujian F-statistik dapat di simpulkan bahwa aspek ekologi, aspek ekonomi dan aspek tehnologi secara bersama - sama berpengaruh terhadap pendapat petani (Y) secara signifikan. Ini dapat kita lihat dimana F-hitung adalah 8.040 dan Ftabel sebesar 2.866 dengan kata lain F-hitung $8.040>$ F-Tabel 2.866. Jadi hipotesis nol ditolak artinya aspek ekologi, aspek ekonomi dan aspek tehnologi secara bersama - sama berpengaruh terhadap pendapat petani (Y). Sedangkan berdasarkan uji t statistik untuk variable bebas yakni aspek ekologi, aspek ekonomi dan aspek tehnologi adalah sebagai berikut : aspek ekologi t hitung sebesar $2.422>$ dari t tabel 2.028, aspek ekonomi t hitung sebesar $2.083>$ dari t tabel 2.028 dan aspek teknologi t hitung sebesar $2.702>$ dari t tabel 2.028. Dengan demikian, aspek ekologi, aspek ekonomi dan aspek tehnologi berpengaruh nyata terhadap pendapat petani tentang PHT.

Kata kunci: lingkungan hidup, pengendalian hama terpadu, pertanian, Kabupaten Bolaang Mongondow Timur, Provinsi Sulawesi Utara 


\section{PENDAHULUAN}

\section{Latar Belakang}

Padi ( Oriza sativa) adalah merupakan bahan makanan pokok atau sumber pangan utama yang sangat penting bagi kebutuhan hidup manusiadan sebagian penduduk Indonesia lainnya. Padi sebagai bahan makanan yang banyak mengandung gizi yang cukup tinggi dan berguna bagi manusia, karena didalamnya terkandung bahan- bahan yang mudah diubah menjadi energi yang sangat kita perlukan setiap hari antara lain protein, karbohidrat, lemak, serat kasar abu dan vitamin, di samping itu beras mengandung unsur-unsur mineral antara lain: kalsium, magnesium, sodium dan fosfor (Anonim, 1990). Padi adalah bahan makanan pokok yang vital bagi penduduk Indonesia, tanaman padi merupakan tanaman kultur yang amat penting bagi manusia karena dikonsumsi oleh hampir separuh dari populasi umat manusia yang ada dibelahan dunia (Steenis, 1981).

Genus Oryza mencakup 20 spesies liar dan 2 spesies dibudidayakan (cultigens). Spesies liar secara luas didistribusikan di daerah tropis dan subtropislembah Afrika, Asia, Amerika Tengah dan Selatan dan Australia. Dua spesies yang dibudidayakan yaitu, Afrika padi (Oryza glaberrima Steud) terbatas dibudidayakan di Afrika Barat, sedangkan beras umum atau beras Asia (Oryza sativa L) sekarang ditanam secara komersial di 112 negara, mencakup semua benua (Smith and Dilday, 2003). Pekerjaan menanam padi khususnya padi sawah telah mendarah daging dan telah dikerjakan hampir seluruh daerah yang ada di Indonesia, karena itu disektor pertanian khususnya padi sawah selalu menjadi prioritas utama dari Pemerintah untuk dikembangkan secara terus menerus. Kebutuhan pangan terutama beras semakin meningkat sejalan dengan bertambahnya penduduk Indonesia, peran sektor pertanian sangat penting dalam mendukung perekonomian nasional karena dari sektor pertanianlah sebagai penyedia bahan pangan dan menjadi mata pencarian sebagian besar masyarakat Indonesia (Adimiharja, 2006). Negara Indonesia adalah negara agraris, sektor pertanian sangatlah penting sebagai ujung tombak dalam mendukung perekonomian nasional terutama penyediaan sandang dan pangan tetapi sungguh ironis karena penghargaan masyarakat terhadap lahan pertanian masih rendah dan tidak professional karena tidak sebanding dengan tingkat manfaatnya (Admihardja, 2006).

Dengan ditingkatkannya intensitas pertanaman padi secara terus menerus akan menyebabkan perubahan ekologi dan terciptanya ekosistem pertanian monokultur. Hal ini merupakan faktor pendorong munculnya Organisme Pengganggu Tanaman (OPT) tertentu yang dapat merusak tanaman. Agroekosistem pada sistem persawahan memiliki keragaman biotik dan genetik yang rendah dan bahkan cenderung semakin tidak beragam, dalam keadaan demikian ekosistem pertanian tanaman padi sawah sangat mudah terjadi peningkatan populasi hama, dengan kondisi yang demikian maka akan meningkatkan populasi OPT apabila penggunaan pestisida tidak sesuai dengan dosis dan anjuran (Untung, 1993). Dengan adanya praktek atau penggunaan pestisida yang terus meningkat dan tidak terkendali maka timbul berbagai masalah karena secara ekonomi dan teknologi pengendalian sudah tidak efisien dan cenderung merugikan sehingga mendorong pemerintah mengeluarkan kebijakan Impres No.3/1986 tentang pelanggaran penggunaan 53 jenis insektisida untuk pengendalian hama, kemudian menjadi tonggak sejarah bagi penerapan pengendalian hama terpadu (PHT) untuk tanaman padi di Indonesia (Untung, 1993). Pembangunan disektor pertanian kini disiapkan untuk memasuki era agroindustri dan agribisnis terpadu, oleh karena itu pengembangan penerapan teknologi yang berwawasan lingkungan dan pengembangan sumberdaya manusia harus mendapat perhatian dan penekanan yang cukup kuat, sebagai landasan pembangunan pertanian yang berkelanjutan dan berwawasan lingkungan.

Pembangunan pertanian yang berwawasan lingkungan, antara lain harus dapat memelihara tingkat kapasitas produksi sumber daya alam yang berwawasan linkungan serta harus dapat mengurangi dampak kegiatan pertanian yang dapat menimbulkan pencemaran dan penurunan kualitas lingkungan hidup. Salah satu kegiatan yang ril yang perlu dilaksanakan adalah bagaimana cara pengamanan produksi pertanian dari gangguan OPT melalui PHT (Oka, 1994). Konsep PHT muncul dan berkembang sebagai koreksi terhadap kebijakan pengendalian hama secara konvensional yang menekan penggunaan pestisida. Penggunaan pestisida dalam kerangka penerapan PHT secara konvensional ini menimbulkan dampak negatif yang merugikan baik ekonomi, kesehatan, maupun lingkungan sebagai akibat penggunaan pestisida yang tidak tepat dan berlebihan (Anonim, 2004). Pemerintah dalam mengatasi kekurangan pagan dimasa mendatang perlu adanya satu terobosan peningkatan produksi padi. Pengalaman dilapangan menunjukan bahwa produktivitas padi masih dapat ditingkatkan melalui 
implementasi program PHT. Penerapan PHT dibidang pertanian diharapkan dapat merubah pola bercocok tanam yang lama yang kurang efisien dan efektif sehingga pada akhirnya dapat meningkatkan produksi dan pendapatan petani itu sendiri. Pada pelaksanaannya PHT tidak terlepas juga dari faktor - faktor yang dapat mempengaruhinya antara lain: lama pendidikan, luas usaha tani, tanggungan keluarga, pengalaman bertani dan umur petani (Mubyanto, 1986). Di Kabupaten Bolaang Mongondow Timur pada tahun 1997 pernah dilaksanakan Sekolah Lapang Pengendalian Hama Terpadu (SLPHT) yang diselenggarakan oleh Dinas Pertanian Dan Peternakan provinsi Sulawesi Utara. Kegiatan ini diikuti oleh beberapa kelompok tani termasuk didalamnya kelompok tani padi sawah. Dengan telah dilaksanakannya kegiatan Sekolah Lapang Pengendalian Hama Terpadu (SLPHT) tersebut maka dianggap perlu dilakukan kajian penerapan PHT pada kelompok tani padi sawah yang sudah mengikuti kegiatan Sekolah Lapang Pengendalian Hama Terpadu (SLPHT) dalam upaya pelestarian lingkungan di Kabupaten Bolaang Mongondow Timur.

\section{Perumusan Masalah}

Berdasarkan uraian diatas perumusan masalah sebagai berikut Bagaimanakah penerapan PHT pada petani padi sawah nyang telah mengikuti kegiatan mpelaksanaan Sekolah Lapang Pengendalian Hama Terpadu (SLPHT) ditinjau dari aspek Ekologi, aspek Ekonomi dan aspek Teknologi di beberapa Kecamatan di Kabupaten Bolaang Mongondow Timur.

\section{Tujuan Penelitian.}

Adapun yang menjadi tujuan penelitian adalah: Untuk mengetahui bagaimana pendapat dan perilaku petani dalam penerapan PHT setelah adanya pelaksanaan kegiatan Sekolah Lapang Pengendalian Hama Terpadu (SLPHT) ditinjau dari aspek ekologi, aspek ekonomi dan aspek teknologi dalam PHT di beberapa Kecamatan di Kabupaten Bolaang Mongondow Timur.

\section{Hipotesis Penelitian}

Diduga petani peserta Sekolah Lapang Pengendalian Hama Terpadu (SLPHT) sudah melaksanakan penerapan PHT pada tanaman padi sawah di Kabupaten Bolaang Mongondow Timur.

\section{Kerangka Penelitian.}

Di era pembangunan pertanian pada saat ini kita masih saja selalu menghadapi masalah antara lain serangan Organisme Penyakit
Tanaman (OPT) serta residu pestisida pada produk pertanian. Dalam mengatasi masalah tersebut pemerintah sudah melaksanakan PHT, dengan menerpakan beberapa komponen PHT yaitu kultur teknis, mekanis, fisik, biologis, dan kimia. Pengendalian dengan konsep PHT merupakan pengendalian yang didasarkan pada prinsip ekologis dengan menggunakan berbagai teknik pengendalian. Program pemerintah dalam pelaksanaan SLPHT adalah satah satu program yang sangat membantu para petani karena petani diajarkan bagaimana melaksanakan PHT dengan melalui berbagai tahapan yuang dilaksanakan satu musim tanam, petani diajarkan bagaimana melakukan budidaya tanaman yang baik, melakukan pengamatan ekosistem persawahan, diajarkan mengenali hama dan penyakit dan musuh alami, diajarkanm bagaimana petani melakukan pengendalian secara bijaksana baik dari aspek ekologi, aspek ekonomi, dan aspek teknologi sehingga dengan melakukan melakukan pengendalian yang secara bijaksana dan bebas dari residu pestisida maka akan tercipta pertanian yang ramah lingkungan. Secara sistematis, kerangka penelitian dalam penelitian ini dapat dilihat pada Gambar 1.

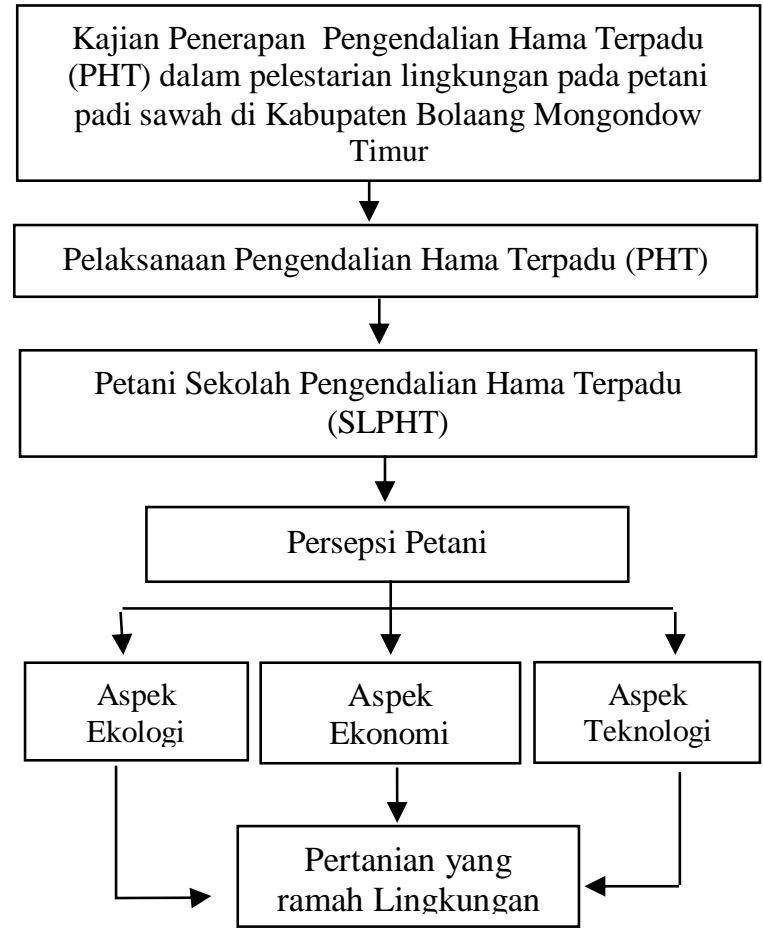

Gambar 1. Kerangka Pemikiran Kajian Penerapan Pengendalian Hama Terpadu (PHT) pada petani padi di Kabupaten Bolaang Mongondow Timur 


\section{METODOLOGI PENELITIAN}

\section{Tempat dan Waktu Penelitian}

Penelitian ini dilakukan di Kabupaten Bolaang Mongondow Timur, Kecamatan Modayag dan Modayag Barat. Pada empat kelompok tani yang mengikuti Sekolah Lapang Pengedalian Hama Terpadu (SLPHT). Penelitian dilaksanakan pada bulan Maret 2016 sampai dengan Juni 2016.

\section{Populasi Penelitian}

Adapun yang menjadi populasi dalam penelitian ini adalah peserta program Pengendalian Hama Terpadu (PHT) yang telah mengikuti sekolah lapang pengendalian hama terpadu (SLPHT) yang ada di kecamatan Modayag dan Kecamatan Modayag barat Kabupaten Bolaang Mongondow Timur.

\section{Sampel penelitian}

Penarikan sampel diawali dengan survey terlebih dahulu untuk mengetahui kondisi dan lokasi penelitian.Pelaksanaan dilakukan secara sampel yaitu 4 (empat) kelompok tani yang mengikuti Sekolah Lapang Pengendalian Hama Terpadu (SLPHT) masing-masing 10 orang atau keseluruhan berjumlah 40 orang dari jumlah kelompok tani yang mengikuti Sekolah Lapang Pengendalian Hama Terpadu (SLPHT) sebagai responden.

2. Pengumpulan data

Penelitian ini menggunakan pengumpulan data sebagai berikut :

\section{a. Data Primer}

Data primer adalah data yang diperoleh dari petani melalui wawancara dengan petani dengan menggunakan daftar pertanyaan (kuisioner). Data yang dibutuhkan tentang karakteristik petani meliputi, umur, pendidikan, luas lahan, pengalaman bertani, kepemilikan lahan pendapat petani tentang aspek ekologi, aspek ekonomi.Aspek teknologi didalam pengendalian hama terpadu (PHT). Adapun wawancara yang dilakukan dengan 2 (dua) cara terstruktur dan tidak terstruktur. Wawancara terstruktur, dalam hal ini dilakukan dengan cara sebelum wawancara terlebih dahulu disiapkan daftar pertanyaan sebagai panduan yang akan dijawab oleh responden pada lembaran jawaban yang telah disediakan, sedangkan wawancara tidak terstruktur dilakukan tanpa menggunakan daftar isian pertanyaan, melakukan wawancara bebas sehingga tidak terjadi kekakuan. Moleong (2007) menjelaskan bahwa petunjuk wawancara hanyalah berisi petunjuk secara garis besar tentang proses dan isi wawancara untuk menjaga agar pokok-pokok yang direncanakan dapat seluruhnya tercakup.

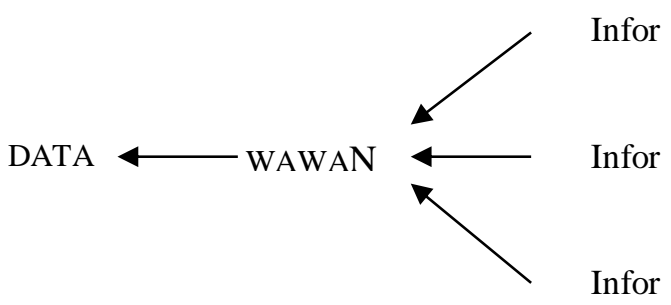

Gambar 2. Bagan Triangulasi

b. Data Sekunder

Data sekunder diperoleh dari penelitian dokumentasi yang berasal dari berbagai sumber yaitu Biro Pusat Statistik Kabupaten Bolaang Mongondow Timur, Dinas Pertanian Bolaang Mongondow Timur, Balai Perlindungan Tanaman Pangan Provinsi Sulawesi Utara.

c. Operasional peubah

Penerapan PHT.

1. Aspek Ekologi

a. Hama

b. Penyakit

c. Penggunaan varietas yang baik dan berlebel

d. Pelestarian musuh alami

e. Waktu pemberian pupuk

f. Sistem pengairan

g. Pengamatan mingguan

2. Aspek Ekonomi

a. Produksi

b. Pendapatan

c. Biaya pengendalian

d. Pertemuan kelompok tani

e. Kunjungan PPL dan PHP

3. Aspek Teknologi

a. Agensi hayati

b. Pestisida

c. Biopestisida

d. Waktu penyemprotan

e. Dosis

f. Jenis-jenis pestisida

4. Pendapat petani tentang Pengendalian Hama Terpadu (PHT)

a. Pengetahuan PHT

b. Manfaat PHT

Data dalam kuisioner dibuat dengan skala likert (Sugiono, 2000). Dengan kriteria keadaan sebagai berikut:

1.) Sangat tidak setuju

2.) Tidak setuju

3.) Kurang setuju

4.) Setuju

5.) Sangat setuju

d. Analisis Data 
Analisis data yang digunakan dalam penelitia ini adalah Analisis Regresi Linier Berganda (Multiple Linier Regression)

Dimana:

$$
Y=a+b 1_{x 1}+b 2_{x 2}+b 3_{x 3}
$$

$Y=$ Pendapat petani

$X_{I}=$ Aspek ekologi

$X_{2}=$ Aspek ekonomi

$X_{3}=$ Aspek teknologi

$a=$ Konstanta

$b_{1}=$ Koefisien regresi $\mathrm{X} 1$

$b_{2}=$ Koefisien regresi X2

$b_{3}=$ Koefisien regresi X3

\section{HASIL DAN PEMBAHASAN}

\section{Karakteristik Responden}

Pengambilan data dengan cara kuisioner dari 40 responden yang mengikuti Sekolah Lapang Pengendalian Hama Terpadu (SLPHT). Karakteristik responden dapat dilihat pada Tabel 4. Terdapat responden petani yang ikut SLPHT keseluruhan yang berjenis kelamin laki-laki 28 responden (70\%) perempuan 12 responden (30\%). Usia responden petani yang ikutSLPHT (Sekolah Lapang Pengendalian Ham Terpadu) yang paling bayak berumur $20 \mathrm{~s} / \mathrm{d} 40$ tahun 34 orang (85\%) dan usia 41 s/d 60 tahun responden $(15 \%)$, dari usia responden di atas dapat dilihat bahwa umur antara $20 \mathrm{~s} / \mathrm{d} 40$ thn yang lebih banyak mengikuti Sekolah Lapang Pengendalian Hama Terpadu (SLPHT) dari pada usia 41 tahun ke atas. Adapun tingkat pendidikan responden bagi petani yang ikut Sekolah Lapang Pengendalian Hama Terpadu (SLPHT) yaitu, 16 responden (40\%) SD, 17 responden (42,5\%) SLTP, 7 responden (17,5\%) SLTA. Dari sini dapat kita lihat bahwa tingkat pendidikan yang paling banyak dimiliki oleh petani yang mengikuti Sekolah Lapang Pengendalian Hama Terpadu (SLPHT) adalah SLTP berarti tergolong pendidikannya masih rendah sehingga masih perlu mengikuti sekolah lapang untuk lebih memahami tentang Pengendalian Hama Terpadu (PHT). Selain pendidikan yang rendah mereka ingin meningkatkan taraf hidup mereka untuk lebih baik dibidang pertanian, hal itulah yang menjadi dasar mereka mengikuti Sekolah Lapang Pengendalian Hama Terpadu (SLPHT). Luas lahan petani yang mengikuti Sekolah Lapang Pengendalian Hama Terpadu (SLPHT) adalah 32 responden $(80 \%)$ dari petani hanya memiliki luas lahan $<0,5$ ha dan 8 responden (20\%) lebih dari 0,5 s/d 1,5 ha, ini berarti di daerah penelitian petani yang memiliki luas lahan yang besar masih kurang. Kepemilikan lahan bagi petani yang ikut Sekolah Lapang Pengendalian Hama Terpadu (SLPHT) yaitu, 23 responden $(57,5 \%)$ yang memiliki lahan sendiri, yang memiliki lahan sewa ada 8 responden $(20 \%)$ dan petani penggarap ada 9 responden $(22,5 \%)$. Ini dapat dilihat bahwa di daerah penelitian di Kabupaten Bolaang Mongondow Timur responden yang ikut Sekolah Lapang Pengendalian Hama Terpadu (SLPHT) masih lebih banyak yang memilikilahan sendiri. Selanjutnya karakteristik responden dapat kita lihat pada Tabel 1 .

Tabel 1. Karakteristik responden yang mengikuti SLPHT pada daerah penelitian

\begin{tabular}{|c|c|}
\hline Uraian & Petani SLPHT \\
\hline \multicolumn{2}{|l|}{ Jenis Kelamin } \\
\hline - Laki-Laki & 28 Responden $(70 \%)$ \\
\hline - Perempuan & 12 Responden $(30 \%)$ \\
\hline \multicolumn{2}{|l|}{ Usia (Thn) } \\
\hline$-20 \mathrm{~s} / \mathrm{d} 40$ & 34 Responden $(85 \%)$ \\
\hline - $\quad 41 \mathrm{~s} / \mathrm{d} 60$ & 6 Responden (15\%) \\
\hline \multicolumn{2}{|l|}{ Pendidikan } \\
\hline$-\quad S D$ & 16 Responden $(40 \%)$ \\
\hline - $\quad$ SLTP & 17 Responden $(42,5 \%)$ \\
\hline - $\quad$ SLTA & 7 Responden $(17,5 \%)$ \\
\hline \multicolumn{2}{|l|}{ Luas Lahan } \\
\hline \multirow[t]{2}{*}{$-<0,5$} & 32 Responden $(80 \%)$ \\
\hline & 8 Responden $(20 \%)$ \\
\hline \multirow{2}{*}{\multicolumn{2}{|c|}{$\begin{array}{l}-\quad>0,5 \mathrm{~s} / \mathrm{d} 1,5 \\
\text { Kepemilikan Lahan }\end{array}$}} \\
\hline & \\
\hline \multicolumn{2}{|l|}{$\begin{array}{ll}- & \text { Milik Sendiri }\end{array}$} \\
\hline \multirow{3}{*}{ - $\quad$ Sewa } & 23 Responden $(57,5 \%)$ \\
\hline & \\
\hline & 8 Responden $(20 \%)$ \\
\hline - $\quad$ Penggarap & 9 Responden $(22,5 \%)$ \\
\hline
\end{tabular}

\section{Deskripsi Jawaban Responden}

\section{Aspek Ekologi}

a. Pendapat petani tentang aspek ekologi mengendalikan hama dengan konsep PHT.

Tabel 2. Frekuensi dan Persentase Petani dalam respons terhadap Aspek Ekologi (Hama)

\begin{tabular}{lll}
\hline Valid & Frequency & Percent \\
\hline 3.00 & 6 & $15, \%$ \\
4.00 & 14 & $35, \%$ \\
5.00 & 20 & $50,0 \%$ \\
\hline Total & $\mathbf{4 0}$ & $\mathbf{1 0 0 , \%}$ \\
\hline
\end{tabular}

Tabel 2 menunjukkan bahwa terdapat $85 \%$ menyatakan bahwa melakukan pengendalian hama dengan konsep PHT dapat menurunkan populasi hama. Konsep PHT adalah cara pendekatan berfikir bagaimana melakukan pengendalian hama dengan menggunakan berbagai taktik pengendalian dalam mempertahankan populasi hama di bawah tingkat ambang kendali (Untung, 1993). Dengan adannya konsep pengendalian ini kebanyakan petani mengadakan pengendalian secara alami terlebih dahulu sebelum menggunakan pestisida seperti mengangkat dan menyebarkan jerami secara merata di persawahan untuk tetap mempertahankan kesuburan tanah serta menambah unsur hara yang ada di dalam tanah, melakukan pengolahan tanah terlebih dahulu sebelum membuat persemaian serta melakukan penanaman serentak untuk menekan populasi hama penggerek batang (Baehaki, 2011). 
b. Pendapat Petani tentang aspek ekologi mengendalikan penyakit dengan konsep PHT.

Tabel 2 menunjukkan bahwa 92,5\% dengan melakukan pengendalian penyakit dengan konsep PHT dapat menurunkan keadaan penyakit tanaman padi sawah antara lain dengan tidak menanam kembali benih yang telah terserang penyakit Tungro karena benih tersebut sudah mengandung virus yang menyebabkan akan timbul kembali penyakit tungro apabila benih padi tersebut masih ditanam. Konsep pengendalian seperti ini adalah pendekatan ekologi yang bersifat multi disiplin karena menggunakan teknik pengendalian yang tidak merugikan secara ekonomi baik bagi manusia, hewan dan lingkungannya (Anonim, 2006).

Tabel 2. Frekuensi dan persentase petani dalam respons terhadap aspek ekologi (penyakit)

\begin{tabular}{lll}
\hline Valid & Frequency & Percent \\
\hline 2.00 & 3 & $7,5 \%$ \\
3.00 & 17 & $42,5 \%$ \\
4.00 & 20 & $50,0 \%$ \\
\hline Total & $\mathbf{4 0}$ & $\mathbf{1 0 0 , \%}$ \\
\hline
\end{tabular}

c. Pendapat Petani tentang Aspek Ekologi Penggunaan Varitas yang baik dan bersertifikat.

Tabel 3 menunjukkan bahwa 92,5\% dengan menggunakan varitas yang baik dan bersertifikat berpengaruh pada hasil produksi ini disebabkan karena ada sebagian petani yang telah menanam benih padi varitas yang berlebel dan bersertifikat dan mereka telah merasakan keunggulan benih berlabel/bersertifikat yang antara lain hasil panen yang lebih tinggi, vigor lebih baik sehingga lebih kompetitif terhadap gulma, aktivitas perakaran yang lebih luas dan kuat sehingga mampu menyerap unsur hara yang lebih banyak, anakan lebih banyak, dan jumlah gabah permalai lebih banyak (Cahyana, 2016).

Tabel 3. Frekuensi dan persentasi petani dalam respons

\begin{tabular}{lll} 
& terhadap aspek ekologi ( penggunaan paritas) \\
\hline Valid & Frequency & Percent \\
\hline 2.00 & 1 & $2,5 \%$ \\
3.00 & 2 & $5 \%$ \\
4.00 & 15 & $37,5 \%$ \\
5.00 & 22 & $55 \%$ \\
\hline Total & $\mathbf{4 0}$ & $\mathbf{1 0 0 \%}$ \\
\hline
\end{tabular}

d. Pendapat petani tentang aspek ekologi pelestarian musuh alami.

Tabel 4 menunjukan bahwa $87,5 \%$ menyatakan dengan mengurangi penggunaan pestisida sintetik akan berpengaruh pada kelestarian musuh alami karena petani telah merasakan manfaat musuh alami serta bahaya pestisida sintetik pada tanaman, hewan dan manusia (Budi, 2014).

Tabel 4. Frekuensi dan persentase petani dalam respons terhadap aspek ekologi (pelestarian musuh alami)

\begin{tabular}{lcc}
\hline Valid & Frequency & Percent \\
\hline 1.00 & 1 & $2.5 \%$ \\
3.00 & 4 & $10 \%$ \\
4.00 & 21 & $52.5 \%$ \\
5.00 & 14 & $35 \%$ \\
\hline Total & $\mathbf{4 0}$ & $\mathbf{1 0 0 \%}$ \\
\hline
\end{tabular}

Bahaya Pestisida Sintetik antara lain:

1. Terganggunya keseimbangan alam karena terbunuhnya musuh alami

2. Terjadinya resistensi dan resujensi Organisme Pengganggu Tanaman

3. Tercemarnya produk yang dihasilkan tanaman

4. Terganggunya kesehatan manusia, hewan dan biota air

5. Terancamnya prodan tanaman, air tanah dan udara

6. Terjadinya keracunan pestisida terhadap manusia dan hewan peliharaan (Said, 1994).

e. Pendapat petani tentang aspek ekologi pengaruh pemupukan

Tabel 5 menunjukkan bahwa 90\% melakukan pemupukan sesuai dengan dosis dan anjuran, ini disebabkan karena sebagian petani sudah mengetahui bahwa pupuk organik dan anorganik dapat menambah unsur hara dalam tanah yang akan meningkatkan pertumbuhan tanaman secara optimal (Suparmudo, 2008).

Tabel 5. Frekuensi dan persentase petani dalam respons terhadap aspek ekologi (pemupukan)

\begin{tabular}{lll}
\hline Valid & Frequency & Percent \\
\hline 2.00 & 4 & $10 \%$ \\
4.00 & 14 & $35 \%$ \\
5.00 & 22 & $55 \%$ \\
\hline Total & $\mathbf{4 0}$ & $\mathbf{1 0 0} \%$ \\
\hline
\end{tabular}

f. Pendapat petani tentang aspek ekologi pengairan teknis.

Dari Tabel 6 menunjukkan bahwa 95\% menyatakan setuju dengan keberadaan pengairan irigasi teknis yang ada di desa karena dengan dibangunnya irigasi teknis dapat mengairi lebih 
luas lagi lahan persawahan, pembagian air dapat secara adil dan merata, ini sejalan dengan Balai Besar Penelitian dan Pengembangan Sumber Daya Lahan Pertanian (2006) bahwa irigasi teknis atau saluran buatan bertujuan untuk memperoleh air dan berfungsi untuk mengairi lahan pertanian.

Tabel 6. Frekuensi dan persentasi petani dalam respons terhadap aspek ekologi (pengairan teknis)

\begin{tabular}{lll}
\hline Valid & Frequency & Percent \\
\hline 3.00 & 2 & $5 \%$ \\
4.00 & 17 & $42.5 \%$ \\
5.00 & 21 & $55.5 \%$ \\
\hline Total & $\mathbf{4 0}$ & $\mathbf{1 0 0} \%$ \\
\hline
\end{tabular}

g. Pendapat petani tentang aspek ekologi mengamatan Mingguan

Tabel 7 menunjukkan bahwa 98\% sering melakukan pengamatan mingguan ini berarti kebanyakan petani sudah mengetahui manfaat pengamatan mingguan, petani dapat melihat dinamika populasi hama dan musuh alami, dapat melihat perkembangan tanaman sehingga petani dapat melihat serangan hama dan penyakit yang sudah diatas ambang kendali atau belum serta petani dapat menentukan cara pengendalian yang akan di lakukan (Untung, 1993).

Tabel 7. Frekuensi dan persentase petani dalam respons terhadap aspek ekologi (pengamatan mingguan)

\begin{tabular}{lll}
\hline Valid & Frequency & Percent \\
\hline 3.00 & 1 & $2.5 \%$ \\
4.00 & 17 & $42.5 \%$ \\
5.00 & 22 & $55 \%$ \\
\hline Total & $\mathbf{4 0}$ & $\mathbf{1 0 0} \%$ \\
\hline
\end{tabular}

\section{Aspek ekonomi}

a. Pendapat petani tentang aspek ekonomi peningkatan produksi

Tabel 8 menunjukkan bahwa $95 \%$ menyatakan produksi meningkat dengan penerapan PHT ini karena didalam kegiatan Sekolah Lapang Pengendalian Hama Terpadu (SLPHT) petani belajar tentang budidaya tanaman yang baik, cara pemupukan, penggolahan tanam yang baik serta pelestarian musuh alami, penggunaan varitas yang baik dan bersertifikat sehingga tanaman mereka tidak terserang hama dan penyakit (Untung, 2006).
Tabel 8. Frekuensi dan persentase petani dalam respons terhadap aspek ekonomi (Produksi)

\begin{tabular}{lll}
\hline Valid & Frequency & Percent \\
\hline 3.00 & 2 & $5 \%$ \\
4.00 & 24 & $60 \%$ \\
5.00 & 14 & $35 \%$ \\
\hline Total & $\mathbf{4 0}$ & $\mathbf{1 0 0} \%$ \\
\hline
\end{tabular}

b. Pendapat petani tentang aspek ekonomi pendapatan petani

Tabel 9 menunjukkan bahwa terdapat 95\% menyatakan pendapatan meningkat karena penggunaan pestisida yang berkurang, mereka melakukan pengendalian dengan melihat tingkat keberadaan musuh alami dan hama yang menyerang tanaman mereka, karena musuh alami adalah pengendali organisme penyakit tumbuhan secara alami yang harus selalu dijaga dan dilestarikan sebagai pengendali organisme penyakit tanaman di alam (Anonim, 2004).

Tabel 9. Frekuensi dan persentase petani dalam respons terhadap aspek ekonomi (Pendapatan)

\begin{tabular}{lll} 
& terhadap aspek ekonomi (Pendapatan) \\
\hline Valid & Frequency & Percent \\
\hline 2.00 & 1 & $2.5 \%$ \\
3.00 & 1 & $2.5 \%$ \\
4.00 & 16 & $40.0 \%$ \\
5.00 & 22 & $55 \%$ \\
\hline Total & $\mathbf{4 0}$ & $\mathbf{1 0 0} \%$ \\
\hline
\end{tabular}

c. Pendapat petani tentang aspek ekonomi biaya pengendalian

Tabel 10 menunjukkan bahwa terdapat 97,5\% menyatakan bahwa setelah mengikuti kegiatan SLPHT dan melakukan penerapan PHT akan mengurangi biaya pengendalian karena petani dalam melakukan pengelolaan lahan pertaniannya ingin mendapat keuntungan yang sebesar-besarnya. Biaya yang dikeluarkan dalam pengendalian hama merupakan total yang dikeluarkan untuk membeli pestisida, varietas yang tahan hama, menyewa alat pengendali hama. Untuk itu petani akan melakukan pengendalian dengan pestisida ketika tingkat serangan hama dan penyakit sudah diatas ambang kendali (Untung, 1994).

Tabel 10. Frekuensi dan persentase petani dalam respons terhadap aspek ekonomi

\begin{tabular}{lll}
\hline Valid & Frequency & Percent \\
\hline 3.00 & 1 & $2.5 \%$ \\
4.00 & 14 & $35 \%$ \\
5.00 & 25 & $62.5 \%$ \\
\hline Total & $\mathbf{4 0}$ & $\mathbf{1 0 0} \%$ \\
\hline
\end{tabular}




\section{d. Pendapat Petani tentang Aspek Ekonomi Pertemuan Kelompok Tani}

Tabel 11 menunjukkan 95\% menyatakan bahwa pendapatan petani akan meningkat dengan seringnya petani melakukan pertemuan dengan PPL dan POPT/PHP karena dalam pertemuan kelompok tani adalah kegiatan pendidikan non formal yang merupakan perpaduan dari kegiatan mengunggah minat atau keinginan, menumbuhkan swadaya masyarakat, menyebarkan pengetahuan, keterampilan, dan kecakapan (Setiana, 2005).

Tabel 11. Frekuensi dan persentase petani dalam respons terhadap aspek e konomi (pertemuan kel. tani)

\begin{tabular}{lll}
\hline Valid & Frequency & Percent \\
\hline 3.00 & 2 & $5 \%$ \\
4.00 & 18 & $45 \%$ \\
5.00 & 20 & $50 \%$ \\
\hline Total & $\mathbf{4 0}$ & $\mathbf{1 0 0} \%$ \\
\hline
\end{tabular}

e. Pendapat petani tenteng aspek ekonomi kunjungan PPL dan PHP

Tabel 12 menunjukkan $92,5 \%$ menyatakan bahwa dengan seringnya PPL dan POPT/PHP melakukan pertemuan dan memberikan penyuluhan tentang budidaya tanaman akan meningkatkan produksi karenakegiatan penyuluhan adalah suatu sistem pendidikan di luar sekolah untuk anggota masyarakat terutama yang ada di pedesaan yang bertujuan untuk meningkatkan pengetahuan, keterampilan, dan sikap mental untuk menjadi lebih produktif sehingga mampu meningkatkan produksi pertaninan dan pendapatan (Setiana, 2005).

Tabel 12. Frekuensi dan persentase petani dalam respons terhadap aspek ekonomi (kunjungan PPL dan PHP)

\begin{tabular}{lll}
\hline Valid & Frequency & Percent \\
\hline 3.00 & 3 & $7.5 \%$ \\
4.00 & 12 & $30 \%$ \\
5.00 & 25 & $62.5 \%$ \\
\hline Total & $\mathbf{4 0}$ & $\mathbf{1 0 0} \%$ \\
\hline
\end{tabular}

\section{Aspek Teknologi.}

a. Pendapat petani tentang aspek teknologi agensi hayati

Tabel 13 menunjukkan bahwa terdapat 92,5\% menyatakan sering melakukan pengendalian dengan agensi hayati ini karena di daerah penelitian sudah ada kelompok tani PPAH (Petani Pengguna Agensi Hayati) yang secara berkelompok membuat agensi hayati misalnya Beuveria. Agensi Hayati adalah setiap Organisme yang dalam semua tahap perkembangannya dapat di gunakan keperluan untuk mengendalikan Organisme Pengganggu Tumbuhan (OPT) dalam proses produksi, pengolahan hasil pertanian dan berbagai keperluan lainnya, (Hidayat, 2016).

Tabel 13. Frekuensi dan persentase petani dalam respons terhadap aspek teknologi (agensi hayati)

\begin{tabular}{lll}
\hline Valid & Frequency & Percent \\
\hline 3.00 & 3 & $7.5 \%$ \\
4.00 & 19 & $47.5 \%$ \\
5.00 & 18 & $45 \%$ \\
\hline Total & $\mathbf{4 0}$ & $\mathbf{1 0 0} \%$ \\
\hline
\end{tabular}

b. Pendapat Petani tentang Aspek Teknologi Pestisida sintetik.

Tabel 14 menunjukkan bahwa terdapat 92,5 $\%$ mengurangi penggunaan pestisida sintetik, ini karena sebagian petani sudah mengetahui bahaya pestisida sintetik pada lingkungan dan manusia, dimana pestisida merupakan bahan pencemar paling potensial dalam budidaya tanaman dan banyak menyebabkan kerusakan lingkungan, (Hendarsih dan Widiarta, 2005).

Tabel 14. Frekuensi dan persentase etani dalam respons terhadap aspek teknologi (pestisida)

\begin{tabular}{lll}
\hline Valid & Frequency & Percent \\
\hline 3.00 & 3 & $7.5 \%$ \\
4.00 & 19 & $47.5 \%$ \\
5.00 & 18 & $45 \%$ \\
& & \\
\hline Total & $\mathbf{4 0}$ & $\mathbf{1 0 0} \%$ \\
\hline
\end{tabular}

c. Pendapat petani tentang aspek teknologi penggunaan bio pestisida

Tabel 15 menunjukkan bahwa terdapat 50\% menyatakan petani tidak pernah menggunakan Bio Pestisida ini karena proses pembuatan Bio Pestisida hanya dapat dilakukan di Laboratorium yang tempat dan peralatan yang memadai dan untuk itu para petugas PPL dan POPT/PHP belum dapat memfasilitasi pembuatan Bio Pestisida di tingkat petani. Bio Pestisida adalah Pestisida yang bersumber pada bahan-bahan alami seperti tumbuhan, hewan, dan mikroba serta feromon serangga untuk mengendalikan serangga (Untung, 2006). 
Tabel 15. Frekuensi dan persentase petani dalam respons terhadap aspek teknologi (bio pestisida)

\begin{tabular}{lll}
\hline Valid & Frequency & Percent \\
\hline 1.00 & 20 & $50 \%$ \\
4.00 & 10 & $25 \%$ \\
5.00 & 10 & $25 \%$ \\
\hline Total & $\mathbf{4 0}$ & $\mathbf{1 0 0} \%$ \\
\hline
\end{tabular}

d. Pendapat petani tentang aspek teknologi paktu Penyemprotan

Tabel 16 menunjukkan bahwa terdapat $72,5 \%$ menyatakan memperhatikan waktu penyemprotan dalam mengendalikan hama dan penyakit karena petani sudah mengetahui waktu penyemprotan yang tepat atau dikenal dengan 6 tepat yaitu: Tepat waktu, tepat dosis, tepat jenis, tepat sasaran, tepat cara dan tepat alat aplikasi (Moekasan, 2014).

Tabel 16. Frekuensi dan persentasi petani dalam respons terhadap aspek teknologi (penyemprotan)

\begin{tabular}{lll}
\hline Valid & Frequency & Percent \\
\hline 3.00 & 11 & $27.5 \%$ \\
4.00 & 10 & $25 \%$ \\
5.00 & 19 & $47.5 \%$ \\
\hline Total & $\mathbf{4 0}$ & $\mathbf{1 0 0} \%$ \\
\hline
\end{tabular}

e. Pendapat petani tentang aspek teknologi dosis dalam penyemprotan pestisida

Tabel 17 menunjukkan bahwa terdapat 82,5 $\%$ memperhatikan dosis dan anjuran dalam aplikasi pestisida karena petani sudah mengetahui kegunaan melakukan penyemprotan sesuai dengan dosis dan anjuran dari petugas, PPL dan PHP/POPT, dosis atau kosentrasi formulasi yang tepat harus sesuai dengan rekomendasi anjuran karena telah diketahui efektif mengendalikan OPT pada suatu jenis tanaman, penggunaan dosis yang tidak tepat akan mempengaruhi efikasi pestisida dan meninggalkan residu pada hasil panen yang membahayakan bagi konsumen. Informasi dosis atau konsentrasi anjuran untuk setiap jenis OPT dapat dilihat pada label atau kemasan pestisida (Moekasan, 2014).

Tabel 17. Frekuensi dan persentase petani dalam respons terhadap aspek teknologi (dosis)

\begin{tabular}{lll}
\hline Valid & Frequency & Percent \\
\hline 3.00 & 7 & $17.5 \%$ \\
4.00 & 14 & $35 \%$ \\
5.00 & 19 & $47.5 \%$ \\
\hline Total & $\mathbf{4 0}$ & $\mathbf{1 0 0} \%$ \\
\hline
\end{tabular}

f. Pendapat petani tentang aspek teknologi jenis pestisida

Tabel 18 menunjukkan bahwa terdapat 97,5\% mengetahui jenis-jenis pestisida karena petani sudah belajar tentang jenis-jenis pestisida yaitu:

1. Insektisida OPT sasaran serangga

2. Akarisida OPT sasaran jenis tunga

3. Rodentisida OPT sasaran tikus

4. Molukisida OPT sasaran siput/keong

5. Fungisida OPT sasaran yang disebabkan oleh cendawan

6. Bakterisida OPT sasaranyang disebabkan oleh bakteri

7. Herbisida untuk pembasmi rumput/gulma (Moekasan, 2014).

Tabel 18. Frekuensi dan persentase petani dalam respons terhadap aspek teknologi (jenis pestisida)

\begin{tabular}{lll}
\hline Valid & Frequency & Percent \\
\hline 3.00 & 1 & $2.5 \%$ \\
4.00 & 15 & $37.5 \%$ \\
5.00 & 24 & $60 \%$ \\
\hline Total & $\mathbf{4 0}$ & $\mathbf{1 0 0} \%$ \\
\hline
\end{tabular}

4. Pendapat petani tentang pengendalian hama terpadu ( Y)

a. Pendapat petani tentang pengetahuan pengendalian hama herpadu

Tabel 19 menunjukkan bahwa terdapat $75 \%$ mendapat pengetahuan tentang PHT karena para petani sangat serius dalam mengikuti kegiatan SLPHT karena mereka sadar didalam kegiatan tersebut mereka memperoleh ilmu yang mereka butuhkan dalam budidaya tanaman padi sawah selama satu siklus perkembangan tanam, belajar menganalisa agro ekosistim dilahan, membuat rencana kelompok, mempresentasikan hasil pengamatan agro ekosistem dilahan persawahan dan mengambil keputusan pengendalian secara bersama (Direktorat Perlindungan Tanaman Pangan. Departemen Pertanian, 2007).

Tabel 19. Frekuensi dan persentasi petani dalam respons terhadap pengetahuan tentang PHT

\begin{tabular}{lll}
\hline Valid & Frequency & Percent \\
\hline 3.00 & 10 & $25 \%$ \\
4.00 & 18 & $45 \%$ \\
5.00 & 12 & $30 \%$ \\
\hline Total & $\mathbf{4 0}$ & $\mathbf{1 0 0} \%$ \\
\hline
\end{tabular}




\section{b. Pendapat Petani tentang manfaat Pengendalian Hama Terpadu (PHT).}

Tabel 20 menunjukkan bahwa terdapat 85\% petani yang mengikuti SLPHT mereka merasakan manfaat PHT pada pertanaman mereka. Mereka dapat memanfaatkan pengendali alami dan mengurangi tindakan-tindakan yang dapat mematian perkembangan musuh alami, pengelolaan ekosistem memlalui usaha bercocok tanam agar lingkungan tanaman kurang sesuai bagi perkembang biakan OPT, penggunaan pestisida secara selektif, pengendalian fisik dan mekanik untuk menekan populasi Organisme Pengganggu Tanaman (OPT), (Untung, 1993).

Tabel 20. Frekuensi dan persentase petani dalam respons manfaat pengendalian hama terpadu.

\begin{tabular}{lll}
\hline Valid & Frequency & Percent \\
\hline 3.00 & 6 & $15 \%$ \\
4.00 & 20 & $50 \%$ \\
5.00 & 14 & $35 \%$ \\
\hline Total & $\mathbf{4 0}$ & $\mathbf{1 0 0} \%$ \\
\hline
\end{tabular}

\section{Analisis persamaan regresi linier berganda}

Mencari persamaan regresi berganda, terlebih dahulu menghitung koefisien-koefisien regresi dengan mencari pengandaan suatu variabel dengan variabel yang lain. Dengan koefisien-koefisien yang didapat dari perhitungan lampiran yaitu, untuk perlakuan pada rumusan permasalahan dan hipotesis, maka didapat persamaan regresi linier berganda pada Tabel 21 .

Tabel 21. Regresi Linier Berganda

\begin{tabular}{clllll} 
Tabel 21. Regresi Linier Berganda \\
\hline Model & $\begin{array}{c}\text { Unsta } \\
\text { ndardi } \\
\text { zed }\end{array}$ & $\begin{array}{c}\text { Cooefficie } \\
\text { nts }\end{array}$ & $\begin{array}{c}\text { Standar } \\
\text { dized } \\
\text { Coeffici } \\
\text { ents }\end{array}$ & T & Sig \\
\cline { 2 - 4 } B & Std. Error & Beta & & \\
\hline (Constan) & 4.240 & 2.593 & & 1.635 & 111 \\
X1 & 074 & 081 & 156 & 2.422 & 362 \\
X2 & 083 & 121 & 132 & 2.083 & 499 \\
X3 & 326 & 121 & 445 & 2.702 & 010 \\
\hline
\end{tabular}

Sumber: Hasil Olahan data, 2016

Diperoleh persamaan regresinya :

$$
\mathrm{Y}=\mathrm{a}+\mathrm{BX}_{1}+\mathrm{B} \mathrm{X}_{2}+\mathrm{BX}_{3}+\mathrm{e}
$$

$\mathrm{Y}=4,240+0,074 \mathrm{X}_{1}+0,083 \mathrm{X}_{2}+0,326 \mathrm{X}_{3}$

a. Konstanta $\mathrm{a}=4,240$

Artinya jika aspek ekologi, ekonomi dan teknologi nilainya 0 (nol), maka pendapat petani tentang PHT nilainya sebesar 4,240.

b. Parameter $\mathrm{BX}_{1}=0,074$

Artinya jika aspek ekologi ditingkatkan sebesar 1 satuan, maka pendapat petani tentang PHT akan naik sebesar 0,074 satuan. c. Parameter $\mathrm{B} \mathrm{X}_{2}=0,083$

Artinya jika aspek ekonomi ditingkatkan 1 satuan, maka pendapat petani tentang PHT akan naik sebesar 0,083 satuan

d. Parameter B X3 = 0,326

Artinya bahwa jika aspek teknologi ditingkatkan 1 satuan, maka pendapat petani tentang PHT akan naik sebesar 0,326 satuan.

\section{Koefisien Determinasi}

Menganalisa dan mengetahui seberapa besar pengaruh faktor faktor yang mempengaruhi pendapat petani tentang PHT, maka dapat dilihat pada Tabel 22.

Tabel 22. Uji Koefisien Determinasi Model Summary

\begin{tabular}{lllll}
\hline Model & R & R Square & $\begin{array}{l}\text { Adjusted } \\
\text { R Square }\end{array}$ & $\begin{array}{l}\text { Std.Error of } \\
\text { the Estimate }\end{array}$ \\
\hline 1 & 633 & 401 & .351 & 1.04379 \\
\hline
\end{tabular}

a. Predictors : (Constant), X1, X2, X3.

$\mathrm{Uji} \mathrm{R}^{2}$ digunakan untuk mengukur seberapa besar variasi (jumlah kuadrat simpangan suatu variabel dari nilai rata-ratanya) dari variabel terikat dapat dijelaskan oleh variabel bebasnya dalam model regresi, sehingga dapat mengetahui kecocokan model regresi tersebut (goodness of fit). Tabel model 26 dapat diketahui bahwa nilai $\mathrm{R}^{2}$ adalah 0,401. Jadi sumbangan pengaruh dari variabel independen yaitu, sebesar 40,1\% sedangkan sisanya sebesar 59,9\% dipengaruhi oleh faktor yang tidak diteliti.

\section{Pengujian Hipeptesis}

\section{Uji F-Statistik}

Uji F-Statistik digunakan untuk mengetahui apakah variabel bebas yakni aspek ekologi (X1) aspek ekonomi (X2) dan aspek teknologi (X3) berpengaruh secara bersama-sama terhadap variabel terikat yakni pendapat petani tentang PHT (Y).

Tabel 23. Analysis of variance ANOVA

\begin{tabular}{llllll}
\hline \multicolumn{1}{c}{ Model } & $\begin{array}{c}\text { Sum of } \\
\text { Sguares }\end{array}$ & Df & $\begin{array}{c}\text { Mean } \\
\text { Squares }\end{array}$ & F & $\begin{array}{c}\text { Si } \\
\text { g. }\end{array}$ \\
\hline Regression & 26.278 & 3 & 8.759 & 8.04 & .0 \\
Residual & 39.222 & 36 & 1.089 & 0 & 00 \\
Total & 65.500 & 39 & & & \\
\hline
\end{tabular}

Predictor(constant): X1,X2,X3

b. Dependent variabel: Y

Prosedur pengujian uji F Statistik adalah sebagai berikut: 
1.) Menentukan hipotesis nol dan hipotesis alternatif

$\mathrm{H}_{\mathrm{o}}: \mathrm{BX}_{1}=\mathrm{B} \mathrm{X}_{2}=\mathrm{BX}_{3}=0$

Artinya aspek ekologi, aspek ekonomi dan aspek teknologi secara bersama-sama tidak berpengaruh terhadap pendapatan petani tentang PHT.

Ha: $\mathrm{BX}_{1} \neq \mathrm{B} \mathrm{X}_{2} \neq \mathrm{BX}_{3} \neq 0$

Artinya aspek ekologi, aspek ekonomi dan aspek teknologi secara bersama-sama berpengaruh terhadap pendapat petani tentang PHT.

2.) Menentukan taraf signifikan.

Taraf signifikan menggunakan 0,05

3.) Menetukan $\mathrm{F}$ hitung dan $\mathrm{F}$ tabel.

F hitung adalah 8,040 (lihat pada tabel 27 ANOVA) F tabel di peroleh dari tabel statistik pada signifikan 0,05 , df1 $=\mathrm{k}-1$ atau $4-1=3$ dan $\mathrm{df} 2=\mathrm{n}-\mathrm{k}$ atau $40-4=36 \quad(\mathrm{k}$ adalah jumlah variabel).

Cara lain mencari $\mathrm{F}$ tabel yaitu menggunakan program Ms Excel nilai $\mathrm{F}$ tabel diperoleh 2,866.

4.) Pengambilan Keputusan $F$ hitung $\leq F$ tabel jadi Ho diterima $\mathrm{F}$ hitung $\geq \mathrm{F}$ tabel jadi Hoditolak

5.) Kesimpulan dapat diketahui bahwa nilai $F$ hitung adalah 8,040 > dari F tabel sebesar 2,866. Jadi hipotesis nol ditolak artinya aspek ekologi, aspek ekonomi dan aspek tehnologi secara bersama-sama berpengaruh terhadap pendapat petani tentang pengendalian hama terpadu (Y).

\section{Uji t}

Uji t-statistik merupakan pengujian untuk mengetahui apakah variabel bebas yakni aspek ekologi (X1), aspek ekonomi (X2) dan aspek tehonologi (X3), secara individu (parsial) mempunyai pengaruh yang signifikan terhadap pendapat petani tentang pengendalian hama terpadu (Y).

Prosedur pengujian adalah sebagai berikut: a. Pengujian aspek ekologi (X1)

1. Menentukan hipotesis nol dan hipotesis alternatif

$$
\mathrm{H}_{\mathrm{o}}=\mathrm{X}_{1}=0
$$

Artinya aspek ekologi tidak berpengaruh terhadap pendapat petani tentang PHT.

$$
\mathrm{H}_{\mathrm{a}} \neq \mathrm{X}_{1} \neq 0
$$

Artinya aspek ekologi berpengaruh terhadap pendapat petani tentang PHT.

2. Menentukan taraf signifikan Taraf signifikan menggunakan 0,05

3. Menetukan $t$ hitung dan t tabel t hitung adalah 2,422 (lihat pada table 25) tabel dapat dicari pada tabel statistik pada signifikasi 0,05/2=0,025 (uji 2 sisi) dengan $\mathrm{df}=\mathrm{n}-\mathrm{k}-1$ atau $40-3-1=36 \quad(\mathrm{k}=$ jumlah variable independen). Cara lain mencari $\mathrm{t}$ tabel yaitu dengan menggunakan program Ms Excel diperoleh t tabel sebesar 2,028.

4. Pengambilan keputusan $\mathrm{t}$ hitung $\leq \mathrm{t}$ tabel jadi Ho diterima $\mathrm{t}$ hitung $\geq \mathrm{t}$ tabel jadi Ho ditolak

5. Kesimpulan

Pada hasil di atas diperoleh bahwa nilan $\mathrm{t}$ hitung sebesar 2,422> dari t tabel sebesar 2,028 sehingga hipotesis nol ditolak, artinya aspek ekologi berpengaruh terhadap pendapat petani tentang PHT.

b. Pengujian aspek ekonomi (X2)

1.) Menentukan hipotesis nol dan hipotesis alternatif

$$
\mathrm{Ho}=\mathrm{X} 2=0
$$

Artinya aspek ekonomi berpengaruh terhadap petani tentang PHT

$$
\mathrm{H} 0 \neq \mathrm{X} 2 \neq 0
$$

Artinya aspek ekonomi tidak berpengaruh terhadap pendapat petani tentang PHT.

2.) Menentukan taraf signifikan

Taraf signifikan menggunakan 0,05

3.) Menentukan $t$ hitung dan $t$ tabel

$\mathrm{T}$ hitung adalah 2,083 (lihat pada tabel coefficients) $\mathrm{t}$ tabel dapat dicari pada tabel statistik pada signifikasi $0,05 / 2=0,025$ (uji 2 sisi) dengan $\mathrm{df}=\mathrm{n}-\mathrm{k}-1$ atau 40-3-1 = $36(\mathrm{k}=$ jumlah variabel independen). Cara lain mencari $\mathrm{t}$ tabel yaitu dengan menggunakan program Ms Excel diperoleh $\mathrm{t}$ tabel sebesar 2,028

4.) Pengambilan keputusan

$\mathrm{T}$ hitung $\leq \mathrm{t}$ tabel jadi Ho diterima

$\mathrm{T}$ hitung $\geq \mathrm{t}$ tabel jadi Ho ditolak

5.) Kesimpulan

Pada hasil di atas diperoleh bahwa nilai $\mathrm{t}$ hitung sebesar 2,083 > dari t tabel sebesar 2,028 sehingga hipotesis nol ditolak, artinya aspek ekonomi berpengaruh terhadap petani tentang PHT.

c. Pengujian aspek teknologi (X3)

1.) Menentukan hipotesis nol dan hipotesis alternatif

$\mathrm{Ho}=\mathrm{X} 1=0$

Artinya aspek teknologi tidak berpengaruh terhadap pendapat petani tentang PHT.

Ho $\neq \mathrm{X} 1 \neq 0$

Artinya aspek teknologi berpengaruh terhadap pendapat petani tentang PHT. 
2.) Menentukan taraf signifikan Taraf signifikan menggunakan 0,05

3.) Menentukan $t$ hitung dan tabel t hitung adalah 2,702 (lihat pada tabel coefficients). $t$ tabel dapat dicari pada tabel statistik pada signifikasi $0,05 / 2=$ 0,025 (uji 2 sisi) dengan $\mathrm{df}=\mathrm{n}-\mathrm{k}-1$ atau $40-3-1=$ 36 ( $\mathrm{k}=$ jumlah variabel independen). Cara lain mencari $\mathrm{t}$ tabel yaitu dengan menggunakan program Ms Excel sehingga diperoleh t tabel sebesar 2,028.

4.) Pengambilan keputusan

$\mathrm{t}$ hitung $\leq \mathrm{t}$ tabel jadi Ho diterima

$\mathrm{t}$ hitung $\geq \mathrm{t}$ tabel jadi Ho ditolak.

5.) Kesimpulan

Pada hasil di atas diperoleh bahwa nilai t hitung sebesar 2,702 > dari $t$ tabel sebesar 2,028 sehingga hipotesis nol ditolak, artinya aspek teknologi berpengaruh terhadap pendapat petani tentang PHT.

\section{KESIMPULAN DAN SARAN}

\section{Kesimpulan \\ Petani peserta SLPHT telah} melaksanakan penerapan PHT pada sistem budidaya tanaman padi sawah di Kabupaten Bolaang Mongondow Timur.

\section{Saran}

Berdasarkan dari hasil penelitian dapat kita lihat bahwa aspek teknologi yang harus lebih ditingkatkan sehingga lingkungan kita lebih aman dari penggunaan pestisida sintetik dan kelestarian lingkungan yang sehat lebih terjaga.

\section{DAFTAR PUSTAKA}

Anonim, 1990 Budidaya Tanaman Padi, Kanisius, Yogyakarta

Anonim, 2007 .Pestisida Action Network Asia and the pasifik pestisida berbahaya bagi kesehatan http// www. Panap.net / uplode / media / Healthmodule . B Indonesia pdf. Pestisida . htm diakses tanggal 15 februari 2015

Adimihardja, A.2006. Strategi mempertahankan multifungsi pertanian Di Indonesia. Jurnal lkitbang pertanian 25 (3) : 99 - 105

Atman Roja 2009 Pengendalian Hama dan Penyakit Secara Terpadu (PHT) Pada Padi Sawah

Anonim, 2004 Kebijakan perlindungan tanaman .Available at : http : // www.deptan.go.id /ditlintp/Kebijakan Perlindungan tanaman htm $\overline{\text { Diakses tanggal } 15}$ januari 2015.
Baehaki, SE 2011 Cstrategi Fundamental Hama Wereng Batang Coklat Dalam Pengamanan Produksi Nasional.

BAPPEDA Kabupaten Bolaang Mongondow Timur 2014, Bolaang Mongondow Timur Dalam Angka.

Balai Perlindungan Tanaman Pangan Dan Hortikultura Provinsi Sulawesi Utara 2015, Laporan Tahunan 2015

Balai besar penelitian dan pengembangan sumber daya lahan pertanian, 2006. Karakteristik dan pengelolaan lahan rawa. DEPTAN, Jakarta.

Budianto, J . 2002. Kebijakan Penelitian dan Pengembangan Pertanian Organik. Makalah Seminar Pertanian Organik Balittro Balitbangtan. Jakarta.

Budi G. 2014. Kebijakan Pertanian Organik Di Indonesia.

Dinas Pertanian dan Peternakan Kabuipaten Bolaang Mongondow Timur 2015, Laporan Tahunan 2015.

Direktorat Perlintan, 2007 Pedoman Sekolah Lapang Pengendalian Hama Terpadu Tanaman Pangan.

Endarsih, 2005 Irigasi Sistim Pengendalian Hama Terpadu Kedalam Model Pengelolaan Tanaman Terpadu.

Moleong, L. J. 2001 Metodologi Penel;itian Kualitatif, Remaja Rodakarya. Bandung

Mubyanto, 1986. Pengantar Ekonomi pedesaan LP3ES. Jaya pirusa.

Setiana, 2005 Teknik Penyuluihan Dan Pemberdayaan Masyarakat. Ghalia Indonesia. Bogor

Smith C. W.and R. H. Dilday2003 Rice : Origin, History, Techno;ogy and Production. John Wiley \& Son, Inc. Hoboken, New Jersey

Suparmudho, 2008 Efisiensi Serapan N Serta Hasil Tanaman Padi Pada Berbagai Imbangan Pupuk Kandang Puyuh Dan Pupuk Anorganik Dilahan Sawah

Steenis V. 1981. Flora Untuk Sekolah Di Indonesia. Pradnya Paramita. Jakarta

Tonny K. Moekasan, 2014 Modul Pelatihan Penggunaan Pestisida Pada Budidaya Cabe Merah Tomat Dan Mentimun

Untung K, 1994 Komsep Strategi Dan Taktik Pengendalian Hama Terpadu Dalam Menunjang Pembangunan Pertanian Yang Berkelanjutan

Untung K, 1995 pengantar pengelolaan hama terpadu , Gadjah mada. University . press, Yogyakarta

Untung K, 2000 Pengendalian Hama Terpadu. Gajah Mada University Prees Yogyakarta.

Untung K, 2006 Pengantar Pengelolaan Hama Terpadu Wadyanto, R, 1997 Teknik Aplikasi Pestisida , Penebar swadaya Jakarta

Wasiati dan Sukirno, 1998 pengendalian hama terpadu ( PHT ) Direktorat bina perlindungan tanaman . Dirjen Tanaman Pangan dan Holtikultura Jakarta 